\title{
Kartlegging av kompetanse er nødvendig for å sikre gode helsetjenester
}

Flere pasienter behandles utenfor sykehus, og det krever at helsepersonell har kunnskapen som trengs for å gi god behandling. Derfor er det nødvendig å kartlegge kompetansen systematisk.

Ann-Chatrin Linqvist Leonardsen

Førsteamanuensis og forsker

Høgskolen i Østfold og Sykehuset Østfold Kalnes

Forsvarlighet

Helsetjeneste

Kvalitet

\section{Hovedbudskap}

Fremtidens helsetjeneste fordrer at det gjennomføres en systematisk kartlegging av kompetansen som kreves for å utføre ulike oppgaver, kompetansen de ulike profesjonsgruppene har, behovet for kompetansehevende tiltak og pasientenes og pårørendes erfaringer med tjenestene. 
Implementeringen av samhandlingsreformen fra 2012 har medført at stadig sykere mennesker mottar avansert medisinsk behandling også utenfor sykehusene. Nye sykehus bygges mindre. Helsepersonell i kommunehelsetjenesten skal i større grad diagnostisere og behandle pasientene, ikke bare gi pleie og omsorg. Andelen eldre og kronisk syke i befolkningen $\varnothing \operatorname{ker}(1,2)$.

Samtidig stilles det større krav til helsetjenesten. Mange har lest seg opp på egen sykdom på nett, de stiller krav, krever medvirkning og forventer digitale tilbud der dette er tilgjengelig (3).

Dette fører til behov for å finne nye løsninger for behandling og pleie både med tanke på hvor helsetjenestene tilbys, $\mathrm{i}$ hvilken form de tilbys, og hvorvidt pasienten skal ivaretas av en helsefagarbeider, verne-/sykepleier eller lege, eller andre samarbeidende helsepersonell som fysio- eller ergoterapeut.

\section{Oppgavefordeling og organisering}

Som sykepleier gjennom 22 år har jeg vært vitne til trendskiftene i bruk av helsepersonell og i organisering av tjenestene.

Da jeg startet som student for over 20 år siden, var hjelpepleierne en anerkjent og viktig del av personalgruppen ved sykehusavdelingene. Deretter kom en periode hvor det kun skulle være sykepleiere ved avdelingene, og hjelpepleierne ble sagt opp. Dette førte til at det ikke var sykepleiere til å dekke stillingene, og hjelpepleierne kom inn som vikarer i sine tidligere stillinger. Nåtidens helsefagarbeidere (hjelpepleiere) får stadig nye oppgaver.

\section{$\equiv$ «Hjelpepleierne kom inn som vikarer i sine tidligere stillinger.»}

Masterutdanninger i sykepleie har fått oppmerksomhet fra

ulike fronter. Noen omtaler dette som «mastersyke», og andre fremhever behovet for masterkompetanse for å møte de nye kravene som stilles i helsevesenet. Det diskuteres hvorvidt sykepleiere med spesialutdanning skal få mulighet til å henvise pasienter til behandling og til å rekvirere ulike legemidler. 
Da jeg startet som student, hadde vi i Østfold fem

lokalsykehus, som så ble slått sammen til ett sentralsykehus.

Nå er trenden ny organisering av tjenestene gjennom

opprettelse av kommunale akuttavdelinger,

korttidsavdelinger og intermediæravdelinger.

Det siste initiativet fra Helse- og omsorgsdepartementet (HOD) er opprettelsen av primærhelseteam, som er team bestående av fastleger, sykepleiere og helsesekretærer. De skal tilby et bedre helsetilbud til pasienter som ikke får god nok oppfølging (1).

I tillegg utvikles ny teknologi, nye løsninger for digital oppfølging av pasienter og ulike e-helse løsninger.

\section{Flere utfordringer}

Behandling av pasienter med komplekse kliniske behov stiller krav til økt kunnskap, trening og kompetanse i håndtering av for eksempel medisinsk-teknisk utstyr som ikke tidligere har vært brukt utenfor sykehus (4). Samarbeidsutfordringer og dårlig koordinering av tjenester er påpekt i en rekke nasjonale rapporter (5-7).

\section{三 «Samarbeidsutfordringer og dårlig koordinering av tjenester er påpekt i en rekke nasjonale rapporter.»}

Studier viste ikke noen $\varnothing \mathrm{kt}$ risiko for pasienter ved å motta desentralisert medisinsk behandling (8-10). Fragmentering av omsorg, et $\varnothing \mathrm{kt}$ antall grensesnitt og pasientoverføringer kan likevel anses som en trussel mot pasientsikkerheten (11). Svakheter ved kommunikasjon og informasjonsoverføring ved utskrivelse fra sykehuset er vanlig og kan påvirke pasientomsorgen negativt (12).

I de kommunale omsorgstjenestene har den hjemmebaserte omsorgen styrket seg i forhold til institusjonsomsorg (sykehjem). Fem av seks tjenestemottakere får omsorgstjenesten i eget hjem, og om lag halvparten av dem bor alene (2). Anette Gohn-Hellum viste i sin masteroppgave at man i hjemmesykepleien slet med lav kompetanse, ubesatte stillinger og høyt sykefravær. Dette får konsekvenser for både kvalitet og pasientsikkerhet. 
Gohn-Hellum konkluderte med at kompetansemobilisering, ved at kompetansen brukes der den trengs mest, er viktig for kvaliteten på tjenesten. At kommunen satser på videreutdanning av de ansatte, er også viktig for kvaliteten på tjenesten og for den enkeltes motivasjon (13).

Solrun G. Holm påpeker i sin doktorgrad at det er behov for forbedringer i hjemmetjenesten, både når det gjelder rutiner og kulturen for hva som blir ansett som akseptabelt.

Sykepleiekompetansen ble opplevd som tilfredsstillende, men ikke tilstrekkelig. Samarbeidet mellom ansatte med ulik kompetanse var utfordrende, og sykepleierne opplevde det som vanskelig å få brukt sin kompetanse på rett sted, til rett tid (14).

\section{Faglig forsvarlighet}

Ifølge helse- og omsorgstjenesteloven (15) skal helse- og omsorgstjenester som tilbys eller ytes, være forsvarlige. Dette innebærer at

- den enkelte pasienten eller brukeren gis et helhetlig og koordinert helse- og omsorgstjenestetilbud,

- den enkelte pasienten eller brukeren gis et verdig tjenestetilbud,

- helse- og omsorgstjenesten og personell som utfører tjenestene, blir i stand til å overholde sine lovpålagte plikter, og

- tilstrekkelig fagkompetanse sikres i tjenestene.

I tillegg har pasienten rett til å medvirke ved valg mellom tilgjengelige og forsvarlige tjenesteformer og unders $\varnothing$ kelsesog behandlingsmetoder.

\section{Sykepleieres kompetanse}

Kompetanse omtales som en kombinasjon av kunnskap, skikkethet, vurderinger og holdninger, men det foreligger ikke noen klar konsensus om innholdet i begrepet kompetanse innen sykepleie $(16,17)$.

Seks kompetanseområder har vært foreslått for opplæring av sykepleieres ferdigheter og holdninger: pasientsentrert omsorg, teamarbeid og samarbeid, evidensbasert praksis, kvalitetsforbedring, sikkerhet og informatikk (18). 
Andre har foreslått områder som profesjonelle/etiske verdier og praksis, sykepleieferdigheter og intervensjoner, kommunikasjon og interpersonlige ferdigheter, kunnskap og kognitive ferdigheter, vurdering og forbedring av kvalitet $i$ sykepleie, profesjonell utvikling, ledelse og teamarbeid og utnyttelse av forskning (19).

WHO beskriver sykepleieres profesjonelle kompetanse som et rammeverk av ferdigheter som reflekterer kunnskap, holdninger og psykososiale og psykomotoriske elementer (20).

\section{三 «Sykepleiere oppgir at de har behov for $\emptyset \mathrm{kt}$ kunnskap, for eksempel i farmakologi og aldersfysiologiske endringer.»}

Sykepleiere oppgir at de har behov for $\varnothing$ kt kunnskap, for eksempel i farmakologi og aldersfysiologiske endringer. Videre er det beskrevet at opplæringen, blant annet i medikamenthåndtering, er mangelfull til tross for at dette er en av arbeidsoppgavene til sykepleiere $(\mathbf{2 1}, \mathbf{2 2})$.

Jeg gjennomførte sammen med kollegaer en kartlegging av sykepleieres egenopplevde kompetanse og behov for mer opplæring i de nyopprettede kommunale avdelingene; kommunal akutt døgnenhet, korttidsavdeling, rehabiliteringsavdeling og palliativ avdeling. akutte, korttid, rehabilitering og palliasjon, og sammenliknet med sykepleieres egenopplevde kompetanse ved tre sykehusavdelinger. Funnene er presentert i en artikkel i Nursing Open (23).

Gjennom denne studien avdekket vi både egenopplevd kompetanse på ulike områder, samt på hvilke områder sykepleierne opplevde at de hadde behov for mer opplæring. For eksempel opplevde sykepleierne å ha lavest kompetanse på å «gi helsefremmende råd og anbefalinger til pasienter via telefon, e-post eller andre digitale løsninger».

De opplevde størst behov for mer opplæring om interaksjoner og bivirkninger av ulike legemidler hos pasientene de er ansvarlig for. Videre avdekket kartleggingen områder som sykepleierne mente var udekket under sykepleierutdanningen, for eksempel kunnskap om kvalitetsog forbedringsarbeid. 
Vi fant en signifikant sammenheng mellom opplevd kompetanse og behov for mer opplæring, hvor $\varnothing$ kt opplevd kompetanse ga redusert behov for mer opplæring.

\section{Systematisk kartlegging}

Jeg mener at fremtidens helsetjeneste fordrer at det gjennomføres en systematisk kartlegging av hvilken kompetanse som kreves for å utføre ulike oppgaver, hvilken kompetanse ulike profesjonsgrupper har, behovet for kompetansehevende tiltak, sammen med kartlegging av pasienters og pårørendes erfaringer med tjenestene.

\section{三 «Jeg mener at fremtidens helsetjeneste fordrer at det gjennomføres en systematisk kartlegging av hvilken kompetanse som kreves for å utføre ulike oppgaver.»}

For å kartlegge kompetansebehov kreves en systematisk tilnærming til hvilke oppgaver som skal ivaretas av hvilke profesjoner. Dette er noe som bør ligge på departementsnivå, for å sikre befolkningen like tjenester uavhengig av hvor de bor.

Verktøyet vi tok i bruk, var «The professional nurse selfassesment scale», ProffNurse SAS, med 50 spørsmål (24). ProffNurse SAS omhandler seks ulike temaer: klinisk praksis, profesjonell utvikling, etisk beslutningstaking, ledelse, samarbeid og konsultering og kritisk tenkning.

Sykepleiere blir bedt om a) å vurdere sin egen kompetanse, b) vurdere sitt behov for mer trening/utdanning og c) angi om dette er dekket i grunnutdanningen.

Til tross for at vi fikk tilbakemelding om at det var et tidkrevende spørreskjema som krevde refleksjon å fylle ut, anser jeg det som et viktig kvalitetsforbedringstiltak å gjennomføre en slik kartlegging, for så å legge systematiske kompetansehevingsplaner. Det finnes også flere ulike verktøy for kartlegging av kompetanse.

Folkehelseinstituttet har en spørreskjemabank med tilgjengelige spørreskjemaer helsetjenestene kan ta i bruk for å kartlegge pasient- og pårørendeerfaringer (25).

Sykehusene er pålagt å gjennomføre pasienterfaringsunders $\varnothing$ kelser jevnlig, mens andre tjenester ikke har samme systematikk for dette. 
Systematiske kartlegginger av helsepersonells kompetanse og kompetansebehov samt pasient- og pårørendeerfaringer er noe som kan utformes og tilpasses lokalt. Min mening er at slike kartlegginger er en forutsetning for å sikre kvalitet og pasientsikkerhet samt likeverdige tjenester for alle.

\section{Referanser}

1. Helse og omsorgsdepartementet. Primærhelseteam - et pilotprosjekt. Oslo; 2018.Tilgjengelig fra:

https://helsedirektoratet.no/primerhelseteam-pilotprosjekt (nedlastet 29.09.2019).

2. Helsedirektoratet. Analyse av utviklingstrekk i omsorgssektoren - utviklingstrekk og endringer som skjer i sektoren. Oslo; 2016.

3. Helse og omsorgsdepartementet. Medisinsk avstandsoppfølging av kronisk syke. Oslo; 2018. Tilgjengelig fra: h ttps://helsedirektoratet.no/tilskudd/medisinskavstandsoppfolging-av-kronisk-syke (nedlastet 29.09.2019).

4. Gautun H, Syse A. Samhandlingsreformen. Hvordan tar de kommunale helse- og omsorgstjenestene imot det $\varnothing \mathrm{kte}$ antallet pasienter som skrives ut fra sykehusene? NOVA; 2013.

5. Grimsmo A, Kirchhoff R, Aarseth T.

Samhandlingsreformen i Norge. Nordiske

Organisasjonsstudier. 2015;17(3):3-12.

6. Grimsmo A, Løhre A. Erfaringer med etablering av kommunalt øyeblikkelig hjelp døgntilbud. Utposten. 2014;43(4).

7. Sundlisæter Skinner M. Enveiskjørt samarbeid? En studie av kommunale ledere og legers erfaringer fra samarbeid med helseforetak om kommunale akutte døgnenheter. Nordisk Tidsskrift for Helseforskning. 2015;2(11):97-112.

8. Aaraas I. Sykestuer i Finnmark. En studie av bruk og nytteverdi. Troms $\varnothing$ : Institutt for samfunnsmedisin; 1998.

9. Garåsen $\mathrm{H}$. The Trondheim Model. Improving the professional communication between various levels of health care services and implementation of intermediate care at a community hospital provide better care for older patients. Trondheim: NTNU; 2008. 
10. Lappegard $\varnothing$. Acute admissions at Hallingdal sjukestugu. Can and should local medical centres play a role in Norwegin healthcare services for acute admissions of a specified group of patients? Oslo: Universitetet i Oslo; 2016.

11. Kongsvik T, Halvorsen K, Osmundsen T, Gjøsund G. Strengthening patient safety in transitions of care: an emerging role for local medical centres in Norway. BMC Health Services Research. 2016;16:452.

12. Kripalani S, LeFevre F, Phillips C, Williams M, Basaviah $\mathrm{P}$, Baker D. Deficits in communication and information transfer between hospital-based and primary care physicians: implications for patient safety and continuity of care. JAMA. 2007;28(8):831-41.

13. Gohn-Hellum A. Idealer og realiteter i hjemmesykepleien. Kan tjenesten være effektiv og ha høy kvalitet på samme tid? (Masteroppgave.)Troms $\varnothing$ : Universitetet i Troms $\varnothing$, Institutt for samfunnsvitenskap; 2016.

14. Norheim K, Thoresen L. Sykepleiekompetanse i hjemmesykepleien - på rett sted til rett tid? Sykepleien Forskning. 2015;1(10)14-22.

15. Lov 1.april 2015 om kommunale helse- og omsorgstjenester m.m. (helse- og omsorgstjenesteloven), §35. Tilgjengelig fra: https://lovdata.no/dokument/NL/lov/2011o6-24-30 (nedlastet 29.09.2019).

16. Cowan DT, Norman I, Coopamah VP. Competence in nursing practice: a controversial concept - a focused review of literature. Nurse education today. 2005;25(5):355-62.

17. Cowan D, Wilson-Barnett J, Norman I, Murrells T. Measuring nursing competence: development of a selfassessment tool for general nurses across Europe. Int J Nurs Stud. 2008;45(6):902-13.

18. Cronenwett L, Sherwood G, Barnsteiner J, Disch J, Johnson JA, Mitchell P, et al. Quality and safety education for nurses. Nurs Outlook. 2007;55(3):122-31.

19. Kajander-Unkuri S, Salminen M, Saarikoski R, Suhonen $\mathrm{R}$, Leino-Kilpi H. Competence areas of nursing students in Europe. Nurse Educ Today. 2013;33(6):625-32. 
20. World Health Organization. Nursing and midwifery. Human resources for health. Geneva: World Health Organization; 2009.

21. Simonsen B, Johansson I, Daehlin G, Osvik L, Farup P. Medication knowledge, certainty, and risk of errors in health care: a cross-sectional study. BMC Health Serv Res. 2011;11:175.

22. Simonsen B, Daehlin G, Johansson I, Farup P. Differences in medication knowledge and risk of errors between graduating nursing students and working registered nurses: comparative study. BMC Health Serv Res. 2014;14:580.

23. Leonardsen A, Bjerkenes A, Rutherford I. Nurse comptence in the interface between primary and tertiary healthcare services. Nursing Open. 2018;6(2):482-92.

24. Finnbakk E, Wangensteen S, Skovdahl K, Fagerström L. The Professional Nurse Self-Assessment Scale: Psychometric testing in Norwegian long term and home care contexts. BMC Nursing. 2015;14:59.

25. Folkehelseinstituttet. Spørreskjemabanken. Oslo: Folkehelseinstituttet; 2018. Tilgjengelig fra: https://www.fhi.no/kk/brukererfaringer/sporreskjemabanken2 I (nedlastet 29.09.2019). 